\title{
An Analysis of the English Language Needs of Medical Professionals Within the Saudi Context: An Exploratory Study in Light of Covid-19 Pandemic
}

\author{
Misfer Ali Hasan Azzhrani (Corresponding author) \\ English Language Institute, King Abdulaziz University \\ Jeddah, Saudi Arabia \\ E-mail: mazzhrani0001@stu.kau.edu.sa
}

Ahmed Alghamdi

English Language Institute, King Abdulaziz University

Jeddah, Saudi Arabia

Received: October 23, 2020 Accepted: November 9, 2020 Published: November 17, 2020

doi:10.5296/ijl.v12i6.17866

URL: https://doi.org/10.5296/ijl.v12i6.17866

\begin{abstract}
This study, based on explanatory sequential, mixed methods, descriptive research design, was conducted at eleven hospitals and medical centers in the city of Makkah in the Western Province in the Kingdom of Saudi Arabia (KSA). The study aimed at exploring the efficacy of the current ESP courses at Saudi tertiary institutes and whether those courses meet the needs of the medical professionals with regards to medical English language proficiency. In addition, the study explored the needs of English medical language proficiency during an international crisis such as the recent corona virus (covid-19) pandemic. The quantitative and qualitative primary data collection was gathered from the medical professionals' responses to a custom designed, twenty-nine items on a psychometric five-point Likert items and open-ended questions, questionnaire. The overall sample population of the medical professional participants in this study was 315 participates (130 male and 185 female participants). The gathered quantitative data from the questionnaire was statistically analysed and the qualitative data gathered from the three open ended questions was analysed for emergent codes using open coding and eventually forming overarching themes. The findings
\end{abstract}


of the study indicated that medical professionals in KSA regard English medical language proficiency as a vital necessity for the profession, especially during an international crisis requiring global communication and cooperation. Furthermore, the majority of the participants indicated that they are not satisfied with the current English language courses provided on the undergraduate level since they felt that rigid and comprehensive English for Specific Purposes (ESP) courses with designated focus on medical English to meet their English language needs are required. Suggestions and emphasis with regards to the provision of medical ESP at tertiary level institutions in KSA are given and possible recommendations for further research investigations in future are also given.

Keywords: ESP, Medical professionals, Needs analysis, Mixed methods research design, Saudi EFL context

\section{Introduction}

\subsection{Background}

Global and international medical cooperation have peaked in the last century, especially with regards to bacterial and viral infections, where medical professionals worldwide have been collaborating and cooperating for the sake of curing diseases and saving lives (Benison, 1982; Gostin, Sircar, \& Friedman, 2019). However, due to the fact that medical professionals around the world speak different languages where it is virtually impossible to establish communication with their peers in every language, it was necessary to use a universal platform which all medical professional can, to a very large extent, understand.

This is even more pressing during a dire situation such as the spread of a pandemic on a global scale such as the coronavirus (covid-19) pandemic which swept worldwide and necessitated continuous international communications amongst medical professionals on all aspects of this coronavirus (covid-19) virus.

As English is becoming more and more established as the lingua franca of the world (Seidlhofer, 2005), it is inevitable to require vital medical information shared amongst medical professional worldwide, to be communicated in English (Tweedie \& Johnson, 2019). Mitrofanova, Andreyeva, Teleshev, and Blyakhman (2018) states that: "As the English language has become a means of communication in the international medical community teaching English for medical purposes is one of the priorities in medical education of non-English speaking countries" (p.127).

However, there has been a seemingly wide gap between tailored and globalised English language courses and the needs of undergraduate students in their professional careers and job requirements with regards to English language proficiency. This is a cause for concern since English languages courses that do not address or foresee the demands and needs of the students following their graduation and joining the job market will subsequently leads to shortfalls and various challenges and difficulties which the newly graduating students will face. This is evident in various research studies which reports on the perception of many tertiary level EFL students who believe they are lacking of sound academic and later in career life, feel that they are increasingly dissatisfied with the ESP courses that do not meet their 
occupational or vocational needs and expectations of a high level of functional proficiency of English language (Karimkhanlouei, 2012; Saragih, 2014). International medical communications or discussions require extensive knowledge of medical English and quick responses with detailed medical terminologies and guidelines in numerous medical aspects and treatments of diseases and illnesses. However, several researchers who have conducted studies in the Saudi context argue for the need to establish English for Specific Purposes (ESP) courses at the university that is aimed at addressing the medical English language low proficiency acquired by medical students (Alfehaid, 2016; Alharby, 2005; Alqurashi, 2016). This is in part due to the fact that the majority of EFL courses, even at an advanced level at colleges or universities do not envisage futuristic purposes, especially for medical students and their future medical career needs (Brunton, 2009).

Despite the fact that several studies have been conducted on needs analysis on ESP with the Saudi medical professionals, there has been a lack of concentrated and focused research on the perceptions and opinions of qualified medical professionals in Saudi Arabia on how an ESP can meet their needs during work conditions and in particular, during an pandemic on a global scale.

\subsection{Significance of the Study}

With the covid-19 pandemic, it is not surprising that a well-established academic curriculum to deliver the English language courses that meet the needs of the Saudi medical professionals is in dire need. Medical professionals in KSA, once they are fully engaged in the medical field both, within KSA and abroad, are in constant communication and cooperation with each other as we have witnessed with the recent covid-19 pandemic where Saudi medical professionals were in constant engagement in discussions with their counterparts from around the world. The covid-19 pandemic brought a whole new arena of medical terms and emphasized many vital medical protocols which are all communicated around the world in English and are constantly been circulated for the sake of combating this pandemic.

Though there are established ESP courses for medical students at various universities in KSA, there still seems to be a lack of voice to be heard from the medical professionals who were these professionals have an invaluable input to be given with regards to what they perceive as either sufficient or lacking with regards to their needs in medical English language (Khan, 2016).

Furthermore, and contrary to the plethora of research studies that discuss the needs analysis from the teachers' perspectives and points of view (Khan, 2016; Kong \& Kong, 2019), this study directs its focus towards the opinion and views of the medical professionals themselves to shed light on their needs regarding the medical English language.

As such, this study, to the researcher's best knowledge, is the first attempt to investigate the medical professionals' perceptions in retrospect regarding what they feel is necessary to be taught and changed (if needed) in relation to the ESP courses taught at colleges and universities. In particular, this study will aim to gather views of both, male and female Saudi 
medical practitioners and allow them to express their views on the challenges and difficulties they face regarding communication with medical practitioners from around the world during a crisis such as the pandemic covid-19.

\subsection{Research Questions}

This research study is guided by the main overarching research of question:

Do the current ESP courses meet the needs of the medical professionals with regards to their medical English proficiency?

The study is further guided by the following three secondary research questions:

1. What are the perceptions of the medical professionals at hospitals in the city of Makkah in Saudi Arabia on the English language needs in their sector? and

2. What are the difficulties that they encounter by using English as their medium of communication during an epidemic such as the corona virus (covid-19)?

3. What possible solutions do medical professionals at hospitals in the city of Makkah feel can contribute towards meeting their needs with regards to medical English proficiency?

\section{Literature Review}

\subsection{The Status of English Language Teaching in KSA}

The English language teaching (ELT) in the Kingdom of Saudi Arabia has been in existence for over eight decades (Elyas \& Picard, 2018). This long journey of ELT in KSA has witnessed noticeable, numerous and extensive changes in all areas of instruction as well as curriculum changes and pedagogical approaches in addition to the adoption of contemporary ELT methodologies which all educational institutes of all levels in KSA, aim to follow in order to elevate the English language proficiency of Saudi students. This is both a necessity as well as an expected reflection on what the Saudi vision 2030 aims to achieve with regards to globalisation which English language teaching and learning is a major pillar in achieving it (Al-Zahrani \& Rajab, 2017). However, and even though the tertiary level institutes in KSA have worked tirelessly in aiming to design English language courses that resemble high international standards, Saudi students still lack those aimed for targets and expected level of English language competency (Al-Jarf, 2008; Alshehri, 2020). Alhamdan, Honan, and Hamid (2017), in their assessment and analysis of the reasons behind such low achievement of English language proficiency among Saudi students, offer a completely different view which looks at the context which students belong to. They state that:

Despite the ubiquity of the discourses of the value and universality of English, there has been limited research on how these discourses unfold in local contexts, how these discourses are reproduced or appropriated, and how these are translated into teaching and learning artefacts (e.g. policies and textbooks) and practices by teachers and students (p. 627). 


\subsection{ESP and Medical English Courses Demand}

In recent times, English communication has become very significant especially in the medical field (Antic, 2007; Le \& Miller, 2020; Maher, 1986). It is not surprising to see that the vast majority of medical literature is available in English language and most of the contemporary approaches to treatment of various major diseases are given and instructed in English. An attempt to browse through the most prominent and renowned medical journals and publications, not to mention the best acclaimed works in the fields of science and technology, are written in English which is unmistakably a strong indicator of the status of English language in the field of medicine. Medical professionals whose English is not their first language and their proficiency in English is not up to a high level or standard, will find themselves missing out on major benefits acquired during medical training, seminars, workshops as well as medical international events since the language in the majority of those events is most likely going to be in English. Thus, it is inevitable that a solid ESP platform for medical professionals is established and a well-drawn plan for designing a curriculum that meets the needs of medical professionals is prepared (Lodhi, Shamim, Robab, Shahzad, \& Ashraf, 2018; Sánchez, Sánchez, Sánchez, \& Rodríguez, 2019). Hyland (2019) specifies two main elements that identify ESP where he indicates that: "English for specific purposes (ESP) refers to language research and instruction that focuses on the specific communicative needs and practices of particular social groups" (p. 391).

The impact of learning medical English has been cited in numerous literature and research studies to such a level that a designated term is given for such a purpose which is: English for Medical purposes (EMP) (Ferguson, 2013; Sinadinović, Mijomanović, \& Aleksić-Hajduković, 2019). As such, medical students who will eventually embark on a medical career need a specialised knowledge of the English language in their medical field which is not merely confined to the knowledge of English for General Purposes (EGP), but rather an EMP, which falls under the umbrella of ESP (Bosher, 2012). Hull (2016) considers EMP as a derived form of specialised English which is rooted in English as a Second Language (ESL) education. He further emphasizes the characteristics of teaching aspects of medical English which need to reflect on the needs of the students as their jobs demand it. The main demands which medical students require for the future career are writing patients' medical progress notes and charting, interviewing, and assessing patients' progress and recovery as well as providing oral and written medical reports to various medical staff and colleagues. As such, it is apparent that a medical student needs to be proficient in the English language skills (i.e. listening, speaking, reading, and writing). Furthermore, it is expected that the latter competency in the four main skills of the language is consolidated with a further proficiency in supplementary language skills such as giving presentations, be involved in discussions, attend academic and medical lectures as well as professional seminars in addition to be competent in conducting workshops relevant to their expertise. 


\subsection{Needs Analysis in English for Specific Purposes}

\subsubsection{Why Needs Analysis?}

In the past three decades, many language researchers took it upon themselves to conduct research studies where they shifted the emphasis of their research work from a linguistic competence (grammar-based pedagogy) stance to an emphasis on communicative competence performance in ELT (Leung, 2005). Shahriari (2014) considers this shift as: "a switch from 'content,' which normally meant grammar and lexis, to 'objectives' which refers to many variables other than linguistic content" (p. 321). He further elaborates on such a shift from content to objectives by focussing on linguistic contents, that such a shift is a result of the growing demand and increased interest in the occupational and vocational linguistics purposes. Subsequently, any specialised language programs have to cater for such needs by the provision of adequate curricula to meet these purposes.

Many researchers, based on such growing demand and pressing needs, emphasize that due to the fact that the number of English language speakers around the world have increased rapidly, a newer pedagogical approaches as well as updated curriculum designs, are required to meet the needs and purposes of the learners (Kaewpet, 2009). Jenkins (2006) believes that it is vital to be aware of the language learners' needs when designing second language courses and prepare lesson objectives in order to facilitate and optimise second-language acquisition (SLA). This is due to the fact that learner group members' needs vary greatly when learning a second or a foreign language since each of different groups aim to achieve a certain level of SLA for different reasons. Some learners aim to acquire a second of foreign language for occupational or vocational reasons while others aim to acquire it for travelling or business endeavours (Belcher, 2006). Conducting needs analysis will highlight the main elements needed in order to be able to know what to include in a particular specialised course. It is the process by which we move from the general and generic course design to more specific and purposefully designed courses (Hyland, 2019). Thus, the area of needs analysis in conjunction with specialised language syllabus (ESP) design has received a surmountable attention in the field of ELT. This is due to the fact that general English (GE) language courses are generally designed on a global scale and in the worst case scenarios, one-size-fits-all courses which have proven to be deficient in that those courses do not cater for cultural sensitivities, the various contexts in which they are needed and above all, they are not designed on the basis of needs analysis of the students (Cobb, 2000; Cohen, 2017). This is particularly true in many EFL contexts where both, teachers and learners express their concerns and reservations regarding curriculum design and resource materials that do not cater for their needs or contexts (Alghamdi \& Alnowaiser, 2017). As such, it not surprising that some general English courses, since lacking differentiation and specific needs of the students, are not expected cater to the individual needs of medical students with regard to real life work and employment situations. The situation becomes more complicated when it comes to exploring the specific needs of the students of medicine with regards to learning English language where those courses focus and keep in view the academic and occupational situations of those medical students (Innocent, 2017). 


\subsubsection{Defining the Needs of Medical Students in ESP Courses}

Otilia (2015) states that: "Needs analysis is considered to be the cornerstone of English for Specific Purposes (ESP)" (p. 54). The process of identifying the important elements of the needs analysis in the curriculum development of an ESP course needs to establish the 'what' and 'how' of the course, as a first step towards the design (Flowerdew, 2013). Obviously, this is: "followed by curriculum design, materials selection, methodology, assessment, and evaluation" (Flowerdew, 2013, p. 325). The Saudi Vision 2030 aims at establishing the Saudization in most important and critical sections of the country and the medical and health field is among these important sections of the country (Elsheikh, Alqurashi, Wahba, \& Hodhod, 2018). However, what is vital is to accelerate such processes in which the needs of the students in KSA are met and catered for. This is due to the fact that several research studies conducted in KSA have expressed their concerns with regards to certain element of deficiencies in certain general English language courses as well as ESP courses (Alsamadani, 2017; Hashmi, Rajab, \& Sindi, 2019; ur Rahman \& Alhaisoni, 2013). In one of the most recent research studies exploring the needs of Business major students at the undergraduate level at a major university in KSA, Alghamdi (2019) believes that current English language programs taught at the tertiary level, does not meet the need of those surveyed and interviewed participant business students. The situation is mirrored in the Saudi medical context where several studies conducted revealed that medical students' needs are not fully met in current English language programs at universities and health colleges (Alqurashi, 2016; Javid \& Farooq, 2015).

\subsection{Covid-19 Pandemic}

The health sector in Saudi Arabia has witnessed a swift transformation in Saudization where it is inevitable that nearly all those Saudi health and medical workers have Arabic as their first language (L1) and this mandates an exploration of the use of the medical English language amongst health and medical workers in Saudi Arabia so as to align this language proficiency with that on a global scale (Yusuf, 2017). As such, it is vital to think about the curriculum development when it comes to the English language element and this is due to the fact that curriculum development is one of the key components in the education process where curriculum developers need to align the goals and objectives of teaching English as a foreign or second language in a particular context so an optimised education outcome is achieved (Alamri, 2019; Elyas \& Badawood, 2016).

With various advancement in medicine and technology coupled with the continuous battles against diseases and illnesses such as cancer, bacterial and viral infections, consorted efforts on a global scale is always needed amongst medical professionals from all over the world. These situations dictate that certain medical terms and phrases as well as diagnostic and treatment protocols are essentially required to be followed so that diseases are eliminated, and illnesses are cured. As previously mentioned, medical professionals whose first language is not English are constantly exposed to medical terms and expressions which might not actually be English in its origins, but rather Latin or Greek (Džuganová, 2017; Pavel, 2014). Subsequently, a medical professional needs to be familiar with such terms, especially in 
situations where new infections or diseases appear and a set of relevant new terms and instructions are required to be given where they are most likely going to be in English language (Biskup \& Wo, 2020). For instance, we have seen such appearances of terms and set of vocabularies with the outbreak of the recent new Corona Virus 2019. Terms such as: epidemic, pandemic, covid-19, SARS-CoV-2, personal protective equipment (PPE), N-95 respirator, as well as being literate and aware of old medical terms such as: oncology, swabs, incubation, virology, quarantine, self-isolation, asymptomatic, ventilator, vaccine, immunocompromised, social distancing, and so on (Grujicic, Radevski, Tuytelaars, \& Blaschko, 2020).

\subsection{Literature Gap}

Several studies have discussed the issue of curriculum design and the medical field in the Saudi context (Nash, 2016). However, the majority of these studies, if not all of them, have explored difficulties and challenges faced by mainly the medical students or newly appointed health professional (Al Rasheed, Naqvi, Ahmad, \& Ahmad, 2017; AlTarawneh \& AlMithqal, 2019; Hassanien, 2018; Memon, Alkushi, Shewar, Anjum, \& Feroz, 2020). This study will explore the perceptions and opinions of medical professionals in the city of Makkah in the Western Region of Saudi Arabia with regards to what they foresee as the best approach towards a curriculum design based on the needs analysis in the medical profession in Saudi Arabia, especially in crisis situation such as the pandemic coronavirus (covid-19) case requiring constant communication with medical professionals from all over the world. It will be an added value to the medical field in KSA since the Kingdom has the expertise of handling outbreaks and epidemics which have, in particular, been gained over the last three decades as well as the eagerness for the Saudi medical professionals to implement the latest and the best medical practices which are consolidated via international medical cooperation and communication.

\section{Methodology}

\subsection{Research Design}

This research study adopted a mixed methods research design in the data collection and analysis phases (Creswell \& Clark, 2017). The study employed the sequential explanatory mixed method design which can be defined as a two-phase model in which collecting quantitative data occur first then followed by the qualitative phase to gain more details (Creswell, 2012; J. W. Creswell, 2014; Johnson \& Onwuegbuzie, 2004).

\subsection{Data Collection Tool}

The study employed a custom designed questionnaire which consisted of twenty-nine items where items 1-7 are demographic in nature. Items 8-25 as well as item 27 are on a five-point Likert items ( 1 = strongly disagree to $5=$ strongly agree) whereas items 26,28 and 29 are open-ended questions. The questionnaires were distributed to eleven medical hospitals and centres in the city of Makkah in KSA and was conducted with a total of 315 (185 female and 130 male) medical professionals participants. 
The items of the questionnaire were divided into three main constructs reflecting on the main research question and the two secondary questions. Table 1 highlights the description of the data collection relating to the constructs and research questions of the study.

Table 1. Description of data collection inventory

\begin{tabular}{|c|c|c|c|}
\hline Section & $\begin{array}{l}\text { Questionnaire } \\
\text { Section name }\end{array}$ & Description of Sections & Scale \\
\hline 1 & $\begin{array}{l}\text { Demographic } \\
\text { information }\end{array}$ & $\begin{array}{l}\text { In this section, the researchers } \\
\text { asked about gender, years of } \\
\text { learning English and specific } \\
\text { medical profession of the } \\
\text { participants. }\end{array}$ & $\begin{array}{l}\text { Nominal data - no } \\
\text { specific scale was used } \\
\text { here. }\end{array}$ \\
\hline 2 & $\begin{array}{l}\text { Perception of ESP } \\
\text { needs and its } \\
\text { importance in the } \\
\text { medical field. }\end{array}$ & $\begin{array}{c}\text { In this section, the medical } \\
\text { professionals reflected on their ESP } \\
\text { needs in their careers }\end{array}$ & $\begin{array}{c}\text { Psychometric, five } \\
\text { points Likert } \\
\text { items ordinal data as } \\
\text { well as the qualitative } \\
\text { data from item } 26 \text { and } \\
\text { 27, of perception and } \\
\text { views. }\end{array}$ \\
\hline 3 & $\begin{array}{l}\text { Challenges and } \\
\text { difficulties of ESP }\end{array}$ & $\begin{array}{l}\text { In this section, the medical } \\
\text { professional participants revealed } \\
\text { the challenges and difficulties they } \\
\text { face with regards to medical ESP }\end{array}$ & $\begin{array}{c}\text { Psychometric, five } \\
\text { points Likert } \\
\text { scale ordinal data of } \\
\text { perception and views. }\end{array}$ \\
\hline 4 & $\begin{array}{l}\text { Possible solutions } \\
\text { to medical ESP } \\
\text { challenges and } \\
\text { difficulties. }\end{array}$ & $\begin{array}{l}\text { In this section, the medical } \\
\text { professional participants expressed } \\
\text { their opinions on what they } \\
\text { perceive as the most effective } \\
\text { solutions to the challenges and } \\
\text { difficulties they face with regards } \\
\text { to medical ESP }\end{array}$ & $\begin{array}{c}\text { Psychometric, five } \\
\text { points Likert } \\
\text { items ordinal data as } \\
\text { well as the qualitative } \\
\text { data from item } 29 \text {, of } \\
\text { perception and views. }\end{array}$ \\
\hline
\end{tabular}

The researchers have posted the questionnaire online and the link to the survey was sent via email to medical professional who agreed to voluntarily participate in this research.

\subsection{Validity and Reliability}

The first step in the data analysis was to pilot the study to ensure the validity of the data collection instrument (i.e. the questionnaire). The gathered data from the piloting study was only used for validation purposes and was not taken into account in the analysis of the main questionnaire data in this research study. Following the piloting of the questionnaire, reliability of the instrument items needed to be tested.

The reliability of the data was evaluated by calculating the internal consistency (stability of items) coefficient, termed the Cronbach's alphas (Taber, 2018). 


\section{Macrothink}

\subsection{Triangulation}

It is worth mentioning here that, by adopting the mixed methods approach, it is considered as a triangulation value added feature which added more richness to the research study and gave it the sense of being more trustworthy in the academic world.

\subsection{The Piloting Stage}

This study was piloted in June 2020 in order to test the questionnaire to be sent to the main participants and identify any potential issues that would affect the data collection procedure and in case of any, modify it accordingly. Ten medical professionals in the city of Makkah were asked to participate in the piloting the questionnaire. The questionnaire was written in English since the targeted sample all spoke a good level in English and there was no need to translate the questions into Arabic. At the end of the piloting time, the participants were asked to elaborate on whether there were any difficulties or ambiguities while responding to the items and they all expressed their satisfaction with the questionnaire.

\subsection{Reliability of the Questionnaire}

The Cronbach's alpha coefficient for the teachers' questionnaire was 0.901 (Table 2).

Table 2. Reliability statistics for the questionnaire

\begin{tabular}{cc}
\hline Cronbach's Alpha & N of Items \\
\hline 0.901 & 29 \\
\hline
\end{tabular}

The above resultant coefficient of $\mathbf{0 . 9 0 1}$ value of the Cranach's Alpha for the questionnaire, gave a clear indication that the questionnaire is reliable.

\subsection{Part I (Demographic Items Data Analysis)}

The first item is related to the gender of the participants. There were 185 female and 130 male, participants as illustrated in Figure 1.

\section{Gender of the Participants}

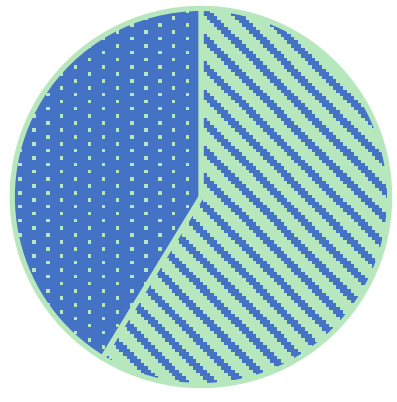

\Female Male

Figure 1. Gender of the participants 


\section{Macrothink}

International Journal of Linguistics

ISSN $1948-5425$

2020, Vol. 12, No. 6

For item 2, the responses of the participants were: physicians at 53\%, nurses at $42 \%$, technicians at $2 \%$ and medical students at $3 \%$. The results are illustrated in Figure 2, below.

\section{Type of Profession}

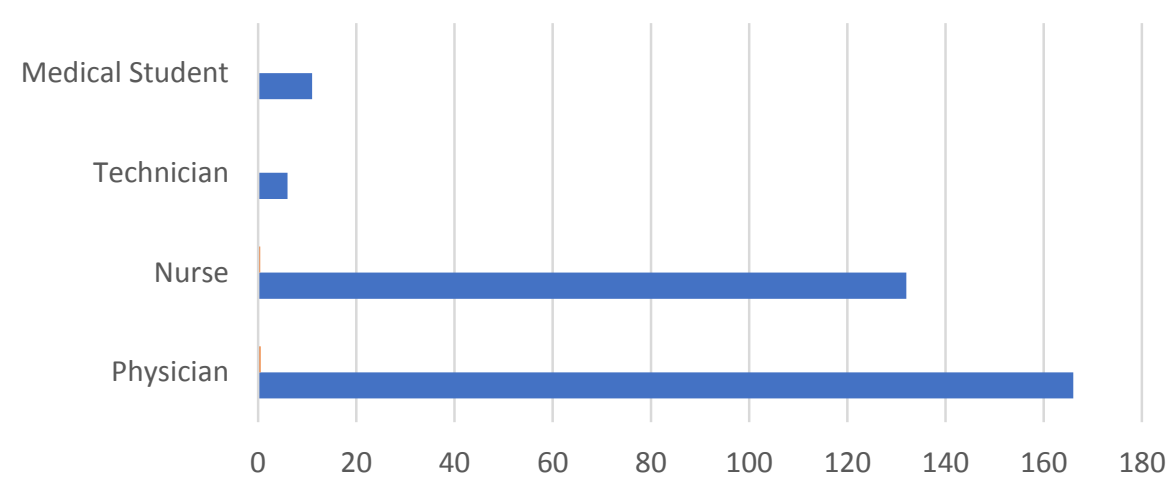

Figure 2. Type of profession of the participants

For item 3, the responses of the participants were: $0-10$ years at 78\%, 11-20 years at 16\%, $21-30$ years at $4 \%$ and $31-40$ years at $6 \%$. The results are illustrated in Figure 3, below.

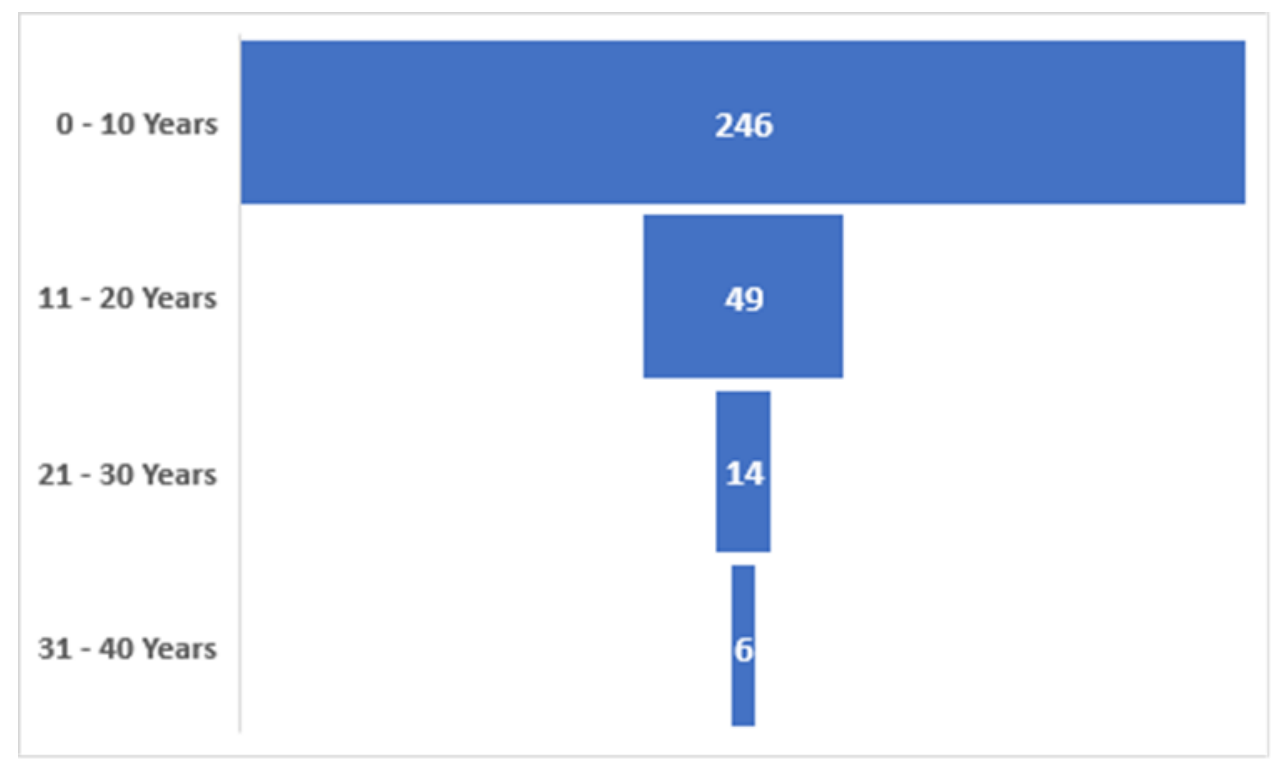

Diagram 3. Years in the medical field

\subsection{Part II (Importance of Learning English)}

The next responses to the items were coded with representative values as following: Strongly Agree $=1$, Agree $=2$, Neutral $=3$, Disagree $=4$, Strongly Disagree $=5$. The results of the participants' responses are illustrated in Table 3 below. 


\section{Macrothink}

Table 3. Part II (importance of learning English) responses

\begin{tabular}{|c|c|c|c|c|c|c|c|c|}
\hline $\begin{array}{l}\text { Item } \\
\text { No. }\end{array}$ & Item/Statement & $\begin{array}{l}\text { Strongly } \\
\text { Agree }\end{array}$ & Agree & Neutral & Disagree & $\begin{array}{l}\text { Strongly } \\
\text { Disagree }\end{array}$ & Total & Mean \\
\hline 8 & $\begin{array}{l}\text { Learning } \\
\text { English } \\
\text { language } \\
\text { becoming is a } \\
\text { must for most } \\
\text { professions }\end{array}$ & $92 \%$ & $5 \%$ & $2 \%$ & $1 \%$ & $0 \%$ & 315 & 1.12 \\
\hline 9 & $\begin{array}{l}\text { Some } \\
\text { professions do } \\
\text { not require } \\
\text { English in their } \\
\text { work } \\
\text { environment }\end{array}$ & $4 \%$ & $16 \%$ & $42 \%$ & $27 \%$ & $11 \%$ & 315 & 3.25 \\
\hline 10 & $\begin{array}{l}\text { In the medical } \\
\text { profession in } \\
\text { Saudi Arabia, } \\
\text { we do not need } \\
\text { to use English } \\
\text { since we } \\
\text { communicate in } \\
\text { Arabic }\end{array}$ & $3 \%$ & $3 \%$ & $10 \%$ & $73 \%$ & $11 \%$ & 315 & 3.86 \\
\hline 11 & $\begin{array}{l}\text { During a } \\
\text { pandemic such } \\
\text { as the covid-19, } \\
\text { medical } \\
\text { professions } \\
\text { from around the } \\
\text { world need to } \\
\text { learn each } \\
\text { other's language } \\
\text { for } \\
\text { communication } \\
\text { purposes }\end{array}$ & $2 \%$ & $3 \%$ & $16 \%$ & $67 \%$ & $13 \%$ & 315 & 3.87 \\
\hline 12 & $\begin{array}{l}\text { English } \\
\text { language is } \\
\text { becoming the } \\
\text { universal } \\
\text { language of } \\
\text { communication } \\
\text { between various } \\
\text { professionals }\end{array}$ & $50 \%$ & $34 \%$ & $3 \%$ & $3 \%$ & $9 \%$ & 315 & 1.87 \\
\hline
\end{tabular}


worldwide

\section{Medical}

professionals, on a national or international

13 level, do not require the

learning of any

language since

medical science

is language-free

\section{English}

language

proficiency does

14 not make a

$2 \%$

$3 \% \quad 4 \%$

$76 \%$

$15 \%$

$315 \quad 3.98$

difference in the

medical

profession

If a medical

English

professional

development

15 course is $60 \%$
announced, you
will register
yourself without
hesitation

As can be seen from table 3 above, the participants had a uniformity of either agreeing or disagreeing on the items. The reflective items on acknowledging the value of English (items 8,12 and 15) had the calculated mean values between $1-2$ which indicates statistical tendency towards agreeing with the statements. However, the participants universally disagreed on the low impact of English language (items 10, 11, 13 and 14). The majority of their responses were in disagreement with these statements and thus, the mean scores were 3.86, 3.87, 4.09 and 3.98, indicating the tendencies towards disagreeing with these statements. 


\subsection{Part III Satisfaction With EAP}

Similar to part II, the collected data for these items were tested for any significant differences among the responses of the male and female participants. The results of the participants' responses are illustrated in Table 4 below.

Table 4. Part III (Satisfaction with EAP) responses

\begin{tabular}{|c|c|c|c|c|c|c|c|c|}
\hline $\begin{array}{l}\text { Item } \\
\text { No. } \\
\end{array}$ & Item/Statement & $\begin{array}{l}\text { Strongly } \\
\text { Agree }\end{array}$ & Agree & Neutral & Disagree & $\begin{array}{l}\text { Strongly } \\
\text { Disagree }\end{array}$ & Total & Mean \\
\hline 16 & $\begin{array}{lr}\text { I am satisfied with } \\
\text { my } & \text { general } \\
\text { knowledge } & \text { of } \\
\text { English. } & \\
\end{array}$ & $54 \%$ & $28 \%$ & $8 \%$ & $7 \%$ & $3 \%$ & 315 & 1.76 \\
\hline 17 & $\begin{array}{l}\text { I am satisfied with } \\
\text { my knowledge of } \\
\text { medical English. }\end{array}$ & $4 \%$ & $16 \%$ & $21 \%$ & $48 \%$ & $11 \%$ & 315 & 3.46 \\
\hline 18 & $\begin{array}{lr}\text { The } & \begin{array}{r}\text { English } \\
\text { language courses } \\
\text { provided during } \\
\text { college } \\
\text { university studies }\end{array} \\
\text { met your aspirations } \\
\text { and needs in the } \\
\text { medical profession }\end{array}$ & $2 \%$ & $4 \%$ & $9 \%$ & $74 \%$ & $11 \%$ & 315 & 3.87 \\
\hline 19 & $\begin{array}{l}\text { The English } \\
\text { language courses } \\
\text { provided at the } \\
\text { university } \\
\text { adequate are } \\
\text { requires no changes } \\
\text { in structure }\end{array}$ & $3 \%$ & $3 \%$ & $14 \%$ & $67 \%$ & $13 \%$ & 315 & 3.84 \\
\hline 20 & $\begin{array}{l}\text { I find reading } \\
\text { medical articles in } \\
\text { English are easy to } \\
\text { read and understand }\end{array}$ & $19 \%$ & $12 \%$ & $23 \%$ & $38 \%$ & $9 \%$ & 315 & 3.07 \\
\hline 21 & $\begin{array}{l}\text { I feel confident } \\
\text { attending meetings } \\
\text { and seminars to } \\
\text { discuss medical } \\
\text { issues in English } \\
\text { language } \\
\text { colleagues from } \\
\text { around the world }\end{array}$ & $3 \%$ & $3 \%$ & $6 \%$ & $60 \%$ & $28 \%$ & 315 & 4.09 \\
\hline
\end{tabular}


During the covid-19 pandemic, I was able to completely

22 follow all the news, $2 \%$ $3 \% \quad 10 \% \quad 70 \%$ $16 \% \quad 315$ information, and updates in English language.

During the covid-19

pandemic, our medical centre (hospital) did not

23 see any need to use the English language or English medical terminologies

At the place of work, we arranged for various meetings with medical professionals from

25 around the world $\begin{array}{lllllll}1 \% & 1 \% & 10 \% & 75 \% & 13 \% & 315 & 3.98\end{array}$ and English was the medium of communication during those meetings The covid-19 pandemic has increased my beliefs in the importance of English language in $\begin{array}{lllllll}76 \% & 14 \% & 6 \% & 3 \% & 1 \% & 315 & 1.39\end{array}$ general and the medical English in particular

The results illustrated in Table 4 above highlights the fact that the participants had also shown a tendency to have a uniformity of responses to the items which are evident in the calculated percentages and means of these items. The responses to items 16, 25 and 27 indicated the agreement of the majority of the participants on the EAP need. On the other hand, the responses to items 17, 18, 19, 20, 21, 22 and 23, highlighted the fact that the majority of the participants universally disagreed with the statements that stated their satisfaction with EAP courses. Thus, the mean scores were 3.46, 3.87, 3.84, 3.07, 4.09, 3.96 and 3.98, indicating the tendencies towards disagreeing with these statements. 


\section{Macrothink}

International Journal of Linguistics

ISSN 1948-5425

2020, Vol. 12, No. 6

With regards to item 24 , the top skill which the participants found challenging during the covid-19 pandemic was medical terminologies at $31 \%$, then the listening skill at $25 \%$, then the speaking skill at $24 \%$, then the reading skill at $11 \%$ and finally, the writing skill at $9 \%$.

\subsection{Analysis of the Open-Ended Questions' Responses (Qualitative Data)}

The qualitative data collected in this study from the three open-ended items: 26, 28 and 29, were fist copied sperately from the rest of the quantitative data and pasted into an MS Word ${ }^{\circledR}$ file where each set of comments for every participants was seprated from the other comments by a divider. Once all the collected data from the three open-ended questions was prepared, the process of the initial coding began immediately.

In what follows are extracts which are purposefully chosen from few participants where these extracts express in more details the perception of the medical professionals who participated in this study. These perceptions are in line with answering the research questions in this study.

\subsection{Analysis of Item 26 Open-Ended Question Sample Responses}

Particpant A (male - physician):

In his responses, the idea of affiring the importance of English is evident and he agrees with the idea that English is vital for medical professionals in their consultations and meetings with internaitonals peer. He states:

Although we did not have a lrage number of meetings with other colleagues internaitonally, however, with the few we did, we spoke in English with everyone. Docotrs from England, Spain, Italy and America ....maybe more...but, we spoke in English because there was not another way to speak in another language for everyone. Ya'ani we can't make it in all these languages.

\subsection{Analysis of Item 28 Open-Ended Question Sample Responses}

Participant B (female - physician)

Alhamdolillah we were ready for the covid-19 pandemic. I have over 15 years of experience with viral infections and I have atrended many conferences in the UK, Canada and the USA. However, this covid-19 is like a big scale and very new. We needed more information from all over the world to support us. We can only do this with English. There is no other way.

\subsection{Analysis of Item 29 Open-Ended Question Sample Responses}

In the following, an accounts from a female particopant to item 29 is given, relating to best solutions to increase knowledge in medical English proficiency, as they see fit. This item was included in the questionnaire in line with answering the third research sub question on the possible solutions to meet the needs of medical profesisonals in the city of Makkah and KSA in general, with regards to the ESP courses. 
Participant C (female - technician)

Participant F, a medical female techinician, gave a detailed account where she expresses her opinion by suggesting various approaches. She states:

I had my medical training in the USA for two years. I had learnt a great deal of medical English which was not provided at my university in Saudi Arabia. But, I cannot see why we cannot have it here in Makkah or at any university in Saudi Arabia. All we need a specialised medical English centre with qualified teahcing faculty where it would be great have those faculty qualified in multi desciplines such as health science and English language teaching. Also, there are many, many textbooks with extremely helpful and easy to follow medical English language which can be taught during a semester or even an intensive two-three weeks courses. Your study is a great way for exploring medical professionals' needs in medical English language and this, can be replicated in such a way, that a periodical quesitonnaire is send to all medical centres in Saudi Arabia (say every six months) to ask those medical professionals about what they might feel necessary to provide for them during a professional development or training. In my opinoin, this is the best approach to cover all the needs of the medical professionals when it comes to specialised English language courses.

In the last account of participant F, we can clearly see that she is aware of the situaiton regarding challenges which medical professionals might ancounter and have presented her suggesitons in that regard.

\section{Main Findings and Conclusions}

The opinions and responses of the participants were unequivocally unified in acknowledging the need of an elevated level of English ESP proficiency in general and during a disease outbreak, necessitating communications between medical professionals around the world. The responses confirmed what is already perceived in the majority of research which emphasise the importance of English as a lingua France in general (Seidlhofer, 2005) and in the medical field in particular (Mitrofanova, Andreyeva, Teleshev, \& Blyakhman, 2018; Tweedie, Johnson, \& Compass, 2019). This opinion was not merely reflected by a particular professional group of the participants in this study, but rather by a sweeping majority of all those who took part in this study. The importance of medical ESP is evidently undeniable. Furthermore, and in response to answering the first, secondary research question where the participants consolidated the agreement on the importance of English language in the medical field, by emphasising that during a pandemic, or otherwise, there is a constant need to communicate with medical professionals worldwide in English and certain areas of medical linguistics such as English medical terminologies, listening as well as speaking skills, which were the main responses of the participants in this study. This was somehow predictable, due to the fact that during professional gatherings, meetings, seminars or otherwise, medical English terminologies are communicated between professionals. The finding is in line with previous research studies by Karimkhanlouei (2012) and Saragih (2014) where they affirmed the need for good medical ESP proficiency in the medical field. 
Leading on from the affirmation of the importance of English in the medical field, came the overall view of challenges and difficulties which some medical professionals face with regards to English ESP. The first general agreement amongst the participants was the lack of contemporary elements as well as the lack of modern medical linguistics regalia where many of the textbooks are a mere simplistic expansion of the main EFL curriculum. The participants clearly expressed their dissatisfaction with the ESP courses offered at the universities they completed their medical courses since it is clear that they felt that there were many challenges faced with regards medical terminologies and communication with professionals worldwide. This is in line with what other researchers reported on the low medical English proficiencies that some students have in their career environment (Alfehaid, 2016; Alharby, 2005; Alqurashi, 2016). This actually brought some interesting responses in the open ended questions in the questionnaire where one participant (Participant D) reflected his opinion on this particular issue by remarking on the negative effect having a low medical English proficiency on his aspirations to promote himself professionally and academically in the medical field. He states:

"I decided not to participate in publishing articles or attend conferences since I felt I need to catch up on the medical language level. It made me stay away from such involvement because I did not want to look like unknowledgeable in the subject"

This was a strong opinion which certainly necissitates a thorough reflection on the efficacy of the medical ESP courses offered at Saudi universities and medical institutes. The fact that KSA has long and established experience with epidemics should lay the assumption that universities are informed about such needs where publishers of endorsed medical ESP textbooks need to update their textbooks to meet the needs and reuirements of the Saudi medical students in the $21^{\text {st }}$ century. Inclusion of the abstract medical information and contents in the ESP medical textbooks is apprantely insufficient in our current day and age necissities for our medical professionals when faced with recent outbreaks of diseases such as the covid-19 pandemic. Dire medical situations that require constant and swift communications between medical professionals around the world where communication is avaliable instantly and to all parts of the world. As such, medical professionals need to be acquainted with all relevant instructions, treatment protocols and other communicated medical procedures in English so that a swift action and a rapid response to emergencies are conducted efficiently and effectively. This was all reflected in the responses of the participants and some have even expressed their disappointements during few of the held meetings with medical professionals in Europe and the United States, where they did not manage to grasp fully certain protocols and procedures that were given during those meetings until it was either translated or explained by other versed medical colleagues.

The previously discussed findings led to the final aim of this study and that is to explore arenas of establishing successful approaches to eliminate such concerns and assist medical professionals in KSA to elevate their medical English proficiencies to a high level. As KSA is approaching 2030 in less than a decade, and in compliance with the Saudi Vision 2030, we need to develop all the communication skills including international medical cooperation and ultimately, medical ESP needs to be optimised to fulfill that task. 


\section{Implications}

Amongst the most suggested solutions was the establishing of a language centre that specialises in delivring medical English to the medical students in a routine and regular well designed and updated ESP courses. Additionally, there were the suggesitons to have a government agency that overlooks the most recently published medical materials and provide it to both, medical students and professionals on a regular bases so that our medical and health care system in KSA is up to the best standards worldwide. Some participants believe that we have the qualified academic professionals who have the ability of providing constant evaluations (say, on a term bases) of the medical ESP materials and as such, make sure that those medical ESP textbooks are up to date and are well tailored to address the needs of the Saudi medical students once they embark on their career endeavour. Furthermore, some participants suggested that invitaitons to highly expeirenced medical professionals from the UK, USA, Canada, Australia and New Zealand, are invited on a regular bases to present the most recent findings where the benefit is double edged in that medical professionals in KSA are well informed about recent developments and advancement in medicine as well as the fact that they are going to be exposed to lectures and seminars in medical English language which will certainly consolidate their knowledge and experience favourably.

\section{Recommendations for Future Research}

It is strongly recommended that this study is conducted with a wider geographical scope so that it includes the major areas of KSA. Also, it would be recommended to include final year medical students as well as faculty members who teach medical ESP courses.

\section{References}

Al Rasheed, F., Naqvi, A. A., Ahmad, R., \& Ahmad, N. (2017). Academic stress and prevalence of stress-related self-medication among undergraduate female students of health and non-health cluster colleges of a public sector university in Dammam, Saudi Arabia. Journal of Pharmacy \& Bioallied Sciences, 9(4), 251.

Alamri, B. (2019). Foreign Culture in English Curriculum in Saudi Arabia: A Teacher's Voice. Arab World English Journal: Special Issue1: Application of Global ELT Practices in Saudi Arabia September. https://doi.org/10.2139/ssrn.3472190

Alfehaid, A. F. (2016). Perspectives of Prospective and Current Healthcare Professionals about the Role of Communicative English Proficiency in the Workplace in Saudi Arabia. Journal of Arabic and Human Sciences, 270(3766), 1-17. https://doi.org/10.12816/0031100

Alghamdi, \& Alnowaiser. (2017). Achieving Flex in the Inflexible: Dealing with Individual Differences in Highly Structured EFL Preparatory College Courses. English Language Teaching, 10(6), 151-159. https://doi.org/10.5539/elt.v10n6p151

Alghamdi. (2019). Exploring English Language Needs: Business Students' and Teachers' Perspectives in a Saudi Undergraduate Context. Arab World English Journal: Special Issue: Application of Global ELT Practices in Saudi Arabia September. https://doi.org/10.2139/ssrn.3472188 
Alharby, M. (2005). ESP target situation needs analysis: The English language communicative needs as perceived by health professionals in the Riyadh area. University of Georgia.

Alqurashi, F. (2016). English for medical purposes for Saudi medical and health professionals. Advances in Language and Literary Studies, 7(6), 243-252. https://doi.org/10.7575/aiac.alls.v.7n.6p.243

Alsamadani, H. A. (2017). Needs analysis in ESP context: Saudi engineering students as a case study. Advances in Language and Literary Studies, 8(6), 58-68. https://doi.org/10.7575/aiac.alls.v.8n.6p.58

AlTarawneh, M. Q., \& AlMithqal, E. A. (2019). Teachers' and Students' Perceptions of Using L1 in the ESP Classroom: A Case of Medical English at an Applied Medical College in Saudi Arabia. Online Submission, 2(3), 19-35.

Belcher, D. D. (2006). English for specific purposes: Teaching to perceived needs and imagined futures in worlds of work, study, and everyday life. Tesol Quarterly, 40(1), 133-156. https://doi.org/10.2307/40264514

Biskup, E., \& Wo, Y. (2020). Medicine in China-Balancing the Progress and the Foundations in Medical Education. Hogrefe AG. https://doi.org/10.1024/1661-8157/a003447

Cobb, T. (2000). One size fits all? Francophone learners and English vocabulary tests. Canadian Modern Language Review, 57(2), 295-324. https://doi.org/10.3138/cmlr.57.2.295

Cohen, J. (2017). English as an International Language in Asia: Implications for Language $\begin{array}{llllll}\text { Education. } \quad \text { Journal } & \text { Asia }\end{array}$ https://doi.org/10.18823/asiatefl.2017.14.1.16.205

Creswell, \& Clark, P. (2017). Designing and Conducting Mixed Methods Research. SAGE Publications.

Creswell, J. W. (2014). A Concise Introduction to Mixed Methods Research. SAGE Publications.

Creswell. (2012). Educational Research: Planning, Conducting, and Evaluating Quantitative and Qualitative Research. Pearson.

Džuganová, B. (2017). Development and Use Of Esp Teaching Materials for Medical Students. Paper presented at the Sbornik Príspěvkủ Z Konference 20. řína 2017 Centrum jazykového vzdělávání.

Elsheikh, A. S., Alqurashi, A. M., Wahba, M. A., \& Hodhod, T. E. (2018). Healthcare Workforce in Saudi Arabia under Saudi Vision 2030. Journal of Health Informatics in Developing Countries, 12(1).

Elyas, T., \& Badawood, O. (2016). English language educational policy in Saudi Arabia post 21st century: enacted curriculum, identity, and modernisation: a critical discourse analysis approach. Paper presented at the FIRE: Forum for International Research in Education. 
https://doi.org/10.18275/fire201603031093

Flowerdew, L. (2013). 17 Needs Analysis and Curriculum Development in ESP. The handbook of English for specific purposes, 325. https://doi.org/10.1002/9781118339855.ch17

Grujicic, D., Radevski, G., Tuytelaars, T., \& Blaschko, M. B. (2020). Self-supervised context-aware Covid-19 document exploration through atlas grounding.

Hashmi, U. M., Rajab, H., \& Sindi, A. E. (2019). Dental Students' Perceptions of ESP Material and its Impact on Their Language Proficiency: A Case Study of a Saudi Arabian University. Arab World English Journal, 10(4). https://doi.org/10.24093/awej/vol10no4.1

Hassanien, M. (2018). Faculty members' perception towards changes in Medical Education in Saudi Arabia. MedEdPublish, 7. https://doi.org/10.15694/mep.2018.0000023.1

Hyland, K. (2019). English for Specific Purposes: Some Influences and Impacts. In X. Gao (Ed.), Second Handbook of English Language Teaching (pp. 337-353). Cham: Springer International Publishing. https://doi.org/10.1007/978-3-030-02899-2_19

Innocent, D. C. (2017). Designing an English for Special Purposes (ESP) Course: The Case of Medical Students. Journal of Language Teaching and Research, 8(3), 447-458. https://doi.org/10.17507/jltr.0803.02

Javid, Z., \& Farooq, U. (2015). Experimenting in-house EMP course contents for Saudi medical undergraduates: Lessons learned. Journal of Critical Inquiry, 13, 38-57.

Jenkins, J. (2006). Points of view and blind spots: ELF and SLA. International Journal of Applied Linguistics, 16(2), 137-162. https://doi.org/10.1111/j.1473-4192.2006.00111.x

Johnson, B., \& Onwuegbuzie, A. (2004). Mixed methods research: A research paradigm whose time has come. Educational Researcher, 33(7), 14-26. https://doi.org/10.3102/0013189X033007014

Kaewpet, C. (2009). A framework for investigating learner needs: Needs analysis extended to curriculum development. Electronic Journal of Foreign Language Teaching, 6(2), 209-220.

Karimkhanlouei, G. (2012). What do Medical Students Need to Learn in Their English Classes?. Journal of Language Teaching \& Research, 3(3). https://doi.org/10.4304/j1tr.3.3.571-577

Leung, C. (2005). Convivial communication: Recontextualizing communicative competence. International Journal of Applied Linguistics, 15(2), 119-144. https://doi.org/10.1111/j.1473-4192.2005.00084.x

Memon, I., Alkushi, A., Shewar, D. E., Anjum, I., \& Feroz, Z. (2020). Approaches used for teaching anatomy and physiology in the university pre-professional program at King Saud bin Abdulaziz University for Health Sciences. Advances in Physiology Education, 44(2), 188-191. https://doi.org/10.1152/advan.00167.2019

Mitrofanova, K. A., Andreyeva, A. V., Teleshev, V. A., \& Blyakhman, F. A. (2018). 


\section{Macrothink}

International Journal of Linguistics

ISSN 1948-5425

2020, Vol. 12, No. 6

Integration of English in Medical Informatics Course for Advanced Medical Education in Russia. Paper presented at the Proceedings of the 12th International Multi-Conference on Society, Cybernetics and Informatics.

Nash, J. A. (2016). New curriculum design and teaching methods to enhance course performance and increase motivation of Saudi Arabian college students. Learning and Teaching in Higher Education: Gulf Perspectives, 13(2). https://doi.org/10.18538/lthe.v13.n2.235

Otilia, S. M. (2015). Needs analysis in English for specific purposes.

Pavel, E. (2014). Teaching English for medical purposes. Bulletin of the Transilvania University of Braşov, Series VII: Social Sciences and Law, (2), 39-46.

Saragih, E. (2014). Designing ESP materials for nursing students based on needs analysis. International Journal of Linguistics, 6(4), 59. https://doi.org/10.5296/ijl.v6i4.5983

Seidlhofer, B. (2005). English as a lingua franca. ELT Journal, 59(4), 339-341. https://doi.org/10.1093/elt/cci064

Shahriari, M. (2014). Medical science graduates'opinions about the esp materials used in college and their language needs at workplace. Modern Journal of Language Teaching Methods, 4(4), 320.

Taber, K. S. (2018). The use of Cronbach's alpha when developing and reporting research instruments in science education. Research in Science Education, 48(6), 1273-1296. https://doi.org/10.1007/s11165-016-9602-2

Tweedie, M. G., Johnson, R. C. J. L., \& Compass, L. (2019). Research Directions in Medical English as a Lingua Franca (MELF), 13(3), e12312. https://doi.org/10.1111/lnc3.12312

Ur Rahman, M. M., \& Alhaisoni, E. (2013). Teaching English in Saudi Arabia: prospects and challenges. Academic Research International, 4(1), 112.

Yusuf, N. (2017). Changes Required in Saudi Universities Curriculum to Meet the Demands of 2030 Vision. International Journal of Economics and Finance, 9(9), 111-116. https://doi.org/10.5539/ijef.v9n9p111

\section{Copyrights}

Copyright for this article is retained by the author(s), with first publication rights granted to the journal.

This is an open-access article distributed under the terms and conditions of the Creative Commons Attribution license (http://creativecommons.org/licenses/by/4.0/) 